\title{
Potential human models of inflammatory bowel disease
}

\author{
STEPHEN B HANAUER MD
}

\begin{abstract}
SB HANAUER. Potential human models of inflammatory bowel disease. Can J Gastroenterol 1995;9(6):316-318. Similar to animal models of inflammatory bowel disease (IBD), there is no single human model representative of ulcerative colitis or Crohn's disease. An optimal human model awaits etiopathogenetic definitions and further reclassification or depiction of clinicopathological scenarios. Current human models can be classified into models depicting risk of disease; preclinical disease; acute inflammation; and miscellaneous IBD. Family studies are the best means of pursuing patients at risk. Evolving genetic and serological markers may further identify subgroups to assess with permeability probes, leukocyte scans or endoscopy for preclinical disease. Provocation with nonsteroidal anti-inflammatory drugs (NSAIDs) may be useful in selected patients because NSAID mucosal damage may induce or mimic IBD. Alternative natural history or interventional studies in patients with human leukocyte antigen (HLA)-B27 spondylarthropathy may be useful. The disease margin and pouchitis are models within the disease state of ulcerative colitis as are the aphthous ulcer, anastomotic margin and diverted fecal stream for Crohn's disease. Newly defined colitides, such as microscopic and collagenous colitis and diversion colitis, also provide potential comparative models to evaluate mucosal immune, inflammatory, reparative, secretory and absorptive regulation.
\end{abstract}

Key Words: Crohn's disease, Genetic models, Human models, Inflammatory bowel disease, Ulcerative colitis

\section{Modèles humains potentiels de maladie inflammatoire de l'intestin}

RÉSUMÉ : Comme c'est le cas pour les modèles animaux de la maladie inflammatoire de l'intestin, il n'y a pas de modèle humain distinct représentatif de la colite ulcéreuse ou de la maladie de Crohn. Un modèle humain idéal pourra être mis au point quand les définitions étiopathogénétiques et autres classifications et descriptions des scénarios cliniques ou pathologiques auront été établies. Les modèles humains actuels peuvent être classés en deux types dépeignant le risque voir page suivante

University of Chicago Medical Center, Chicago, Illinois, USA

Correspondence: Dr SB Hanauer, University of Chicago Medical Center, 5841 Maryland Avenue, Chicago, IL 60637, USA. Telephone 312-702-1466, fax 312-702-2182, e-mail shanauer@med.bsd.uchi.edu

This paper was presented at the Trends in Inflammatory Bowel Disease Therapy meeting, April 6 to 9, 1994, held in Victoria, British Columbia. This paper has also been published in Sutherland LR, et al, eds. Inflammatory Bowel Disease: Basic Research, Clinical Implications and Trends in Therapy. Boston, Dordrecht and London: Kluwer Academic Publishers, 1994
HE ABSENCE OF AN ANIMAL
model that correlates with the course of either ulcerative colitis or Crohn's disease has impeded basic research to define the etiopathogenesis of inflammatory bowel disease (IBD) and clinical research involving potential therapeutic agents. Basic progress in animal (primarily mouse) gene typing accompanied by both knock-out and transgenic techniques may, eventually, identify genetic predispositions that apply to human IBD. Meanwhile, continued clinical research in IBD has elucidated many aspects of the immune and inflammatory cascades contributing to the pathogenesis of ulcerative colitis and Crohn's disease, which may translate into a better understanding of the clinical manifestations and disease course and may promise eventual therapeutic improvements. Concurrently, new serological markers (eg, antineutrophil cytoplasmic antibodies [ANCA]) and genetic phenotypic markers (eg, human leukocyte antigen [HLA]-DR2) offer potential correlates to clinical subgroups that may clarify aspects of the heterogeneity within IBD. The diversity among patients and the evolving epidemiology of IBD as ethnic populations assume western diets and culture (including smoking) suggest that an eventual reclassification of IBD is likely. We need to continue to consider these possibilities while searching for subsets of human models of IBD. Meanwhile, there are a number of potential models that 
de maladie, la maladie préclinique, l'inflammation aiguë et la diversité des MII. Le suivi auprès des familles est le meilleur moyen de prendre en charge les patients à risque. L'évolution des marqueurs génétiques et sérologiques peut aider à identifier davantage les sous-groupes à évaluer à l'aide de tests de perméabilité, de scanographies leucocytaires ou d'endoscopies pour la maladie au stade préclinique. Les épreuves de provocation à l'aide d'anti-inflammatoires non stéroïdiens peuvent être utiles chez certains patients parce que les lésions de la muqueuse causées par les AINS peuvent provoquer ou imiter les MII. D'autres épreuves axées sur l'histoire naturelle ou sur les résultats d'intervention chez les patients atteints de spondylarthropathie associée à l'antigène leucocytaire humain (HLA)-B27 peuvent être utiles. Les rebords des zones lésées et la pouchite peuvent servir de modèle en présence de colite ulcéreuse, tout comme l'ulcère aphteux, la marge anastomosique et la dérivation fécale dans la maladie de Crohn. Les colites nouvellement définies, comme la colite microscopique et collagénique et la colite de dérivation offrent également des modèles comparatifs potentiels pour évaluer les mécanismes immunitaires, inflammatoires, réparateurs, sécréteurs et absorbants de la muqueuse.

can be used to study the pathogenesis and natural history of and therapies for IBD.

\section{RISK FACTORS}

Several risk factors for IBD development may be considered as models in predisposed individuals to distinguish the susceptibility towards environmental exposure, injury or both. The family history of IBD presents the most available means of evaluating potential candidates for developing disease. Linkage studies are underway that may eventually identify patients at risk, as may serological studies (eg, using perinuclear antineutrophil cytoplasmic antibodies [pANCA]). Unfortunately, there is no facile means of assessing preclinical disease. Therefore, the natural history of relatives with identified markers such as HLA-DR2 or pANCA should be observed, especially in 'multiplex' families. Testing these individuals affords the potential to measure other possible preclinical markers or response parameters. For instance, intestinal permeability has been used with variable results in active and quiescent IBD and as a marker for preclinical relapse (1). The original finding of increased permeability in family members of Crohn's disease patients has not been verified (2); however, the concept of permeability as a potential marker should not be abandoned. Further, provocative permeability testing using nonsteroidal anti-inflammatory drugs (NSAIDs) may increase the sensitivity of permeability studies (3). The influence of cigarette smoking on permeability in relatives of IBD patients could also be explored, especially in relatives of ulcerative colitis patients who may have an increased risk of developing clinical disease if they have stopped smoking. It would be of great interest to evaluate family members documented to have increased permeability with additional studies such as leukocyte scans or even ileocolonoscopy to rule out preclinical mucosal/histological disease.

\section{PRECLINICAL MARKERS}

Preclinical markers of IBD may also be identified in patients with recognized predisposing diseases such as HLA-B27-associated spondylarthritis. Patients with ankylosing spondylitis have a high incidence of associated ileitis with endoscopic and histological features that are indistinguishable from those of Crohn's disease (4). Additional studies of mucosal immune function in these individuals should provide insight into both initiating (or predisposing) and amplifying factors (5). Few natural history studies have been performed in this subgroup of patients.

NSAID-induced small bowel and colonic damage have recently been observed to mimic many of the mucosal (and potentially clinical) features of IBD (6). This provides the opportunity to evaluate both a risk factor for IBD in susceptible individuals (eg, relatives) and the normal reparative mechanisms that may be absent or deficient (including eicosanoids, cytokines and growth factors). Alternative acute models of idiopathic IBD include enterocolitides of known etiology such as infectious, ischemic or radiation-induced mucosal damage where there is the potential to measure regulatory immune, inflammatory events and tissue repair in healthy individuals, and in IBD patients and relatives.

\section{POTENTIAL MODELS}

Potential models of IBD exist even within the disease course. In ulcerative colitis there are two excellent models to assess mucosal events: the margin of disease and pouchitis. The margin between active inflammation and 'normal' mucosa has been inadequately studied. Most often patients with distal colitis are included with pancolitics when mediators or histology are examined. The disease margin is a prototype for defining mucosal abnormalities in the same individual with an identical genetic disposition. Local immune, inflammatory and regenerative features need to be studied in patients. Likewise, pouchitis offers another example of an aberrant tissue response to (presumably) similar environmental exposures in patients with ulcerative colitis and familial polyposis. Genetic dispositions can be compared among these groups but, even among ulcerative colitis patients, the natural history of pouchitis (beginning with the diverted or naive pouch followed by bacterial proliferation) and the defined risk for subclinical and clinical disease, as well as the potential for healing with antibiotic therapy, offer the opportunity to study patients in a sequential fashion (7). It appears that risk factors may also predictably be applied to patients before ileal pouch formation, such as the presence of extraintestinal manifestations or pANCA.

Potential models for the study of Crohn's disease also exist within the disease spectrum and clinical course. The aphthous ulcer occurs in healthy individuals, in patients with NSAID exposure and as isolated findings as a presumed 'primary' lesion or event in 
Crohn's disease. Further exploration of the immunoinflammatory and mediator events in and around these Crohn's, infectious or NSAID-induced lesions offers additional insight into pathogenic differences. Two additional models of Crohn's disease include the anastomotic site and fecal diversion. The predisposition for Crohn's disease to recur at the proximal to the anastomotic margin affords the potential to monitor mucosal events sequentially; this has recently been the focus of several interventional studies to prevent prophylaxis or alter both endoscopic and clinical disease. Similarly, diversion of the fecal stream in Crohn's disease of-

\section{REFERENCES}

1. Hollander D. The intestinal permeability barrier: a hypothesis as to its regulation and involvement in Crohn's disease. Scand J Gastroenterol 1992;27:721-6.

2. Munkholm P, Langholz E, Hollander $\mathrm{D}$, et al. Intestinal permeability in patients with Crohn's disease and ulcerative colitis and their first degree relatives. Gut 1994;35:68-72.

3. Pironi L, Miglioli M, Ruggeri E, et al. Effect of non-steroidal antiinflammatory drugs (NSAID) on intestinal permeability in first degree relatives of patients with Crohn's disease. Gastroenterology 1992;102:A679.

4. Mielants H, Veys EM, Goemaere S, fers an alternative model to study the inflammatory process (8).

A number of newly described colitides also need to be examined as models for IBD as additional epidemiological, clinical, histopathological, immune and associated factors are explored. The recent recognition of collagenous, microscopic diversion and human immunodeficiency virus (HIV)-associated enterocolitis affords the opportunity to examine potential similarities and differences with the classic IBD syndromes (9).

\section{CONCLUSIONS}

In the examination and evaluation of these and other potential human Cuvelier C, DeVos M. A prospective study of patients with spondyloarthropathy with special reference to HLA-B27 and to gut histology. J Rheumatol 1993;20:1353-8.

5. Cuvelier CA, DeWever N, Mielants H, DeVos M, Veys EM, Roels H. Expression of T cell receptors alpha beta and gamma delta in the ileal mucosa of patients with Crohn's disease and with spondylarthropathy. Clin Exp Immunol 1992;90:275-9.

6. Bjarnason I, Hayllar J, MacPherson AJ, Russell AS. Side effects of nonsteroidal anti-inflammatory drugs on the small and large intestine in humans. Gastroenterology 1993;104:1832-47.

7. Luukkonen P, Jarvinen H, Tanskanen models of IBD it is important not to limit ourselves to current paradigms of etiopathogenesis (10). We must be humbled by the recent example of the discovery of Helicobacter pylori in peptic ulcer disease. When confronted with the current dogma seeking an immunological 'truth' as a predisposing cause of IBD, we should remain open to alternative hypotheses including dysfunctional epithelium, alternative microorganisms (including viral vasculitis and epithelial bacteria) and molecular mimicry or autoimmunity, and use these concepts for hypothesis testing rather than decreeing them exceptions to our current conceived formulations on etiopathogenesis.

M, Kahri A. Pouchitis - recurrence of the inflammatory bowel disease? Gut 1994;35:243-6.

8. Winslet MC, Allan A, Poxon V, Youngs D, Keighley MRB. Faecal diversion for Crohn's colitis: A model to study the role of the faecal stream in the inflammatory process. Gut 1994;35:236-42.

9. Kingsmore SF, Kingsmore DB, Hall $\mathrm{BD}$, Wilson JAP, Gottfried MR, Allen NB. Co-occurrence of collagenous colitis with seronegative spondylarthropathy: Report of a case and literature review. J Rheumatol 1994;20:2153-7.

10. Kuhn TS. The Structure of Scientific Revolutions. Chicago: University of Chicago Press, 1962. 


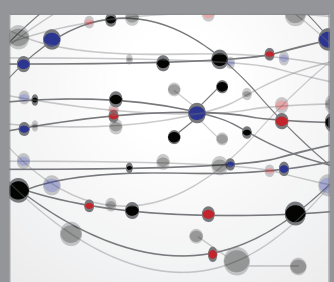

The Scientific World Journal
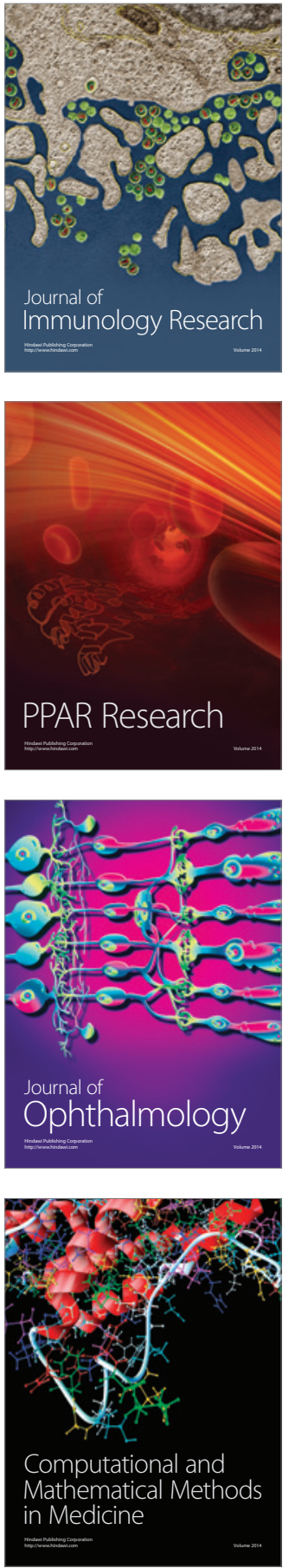

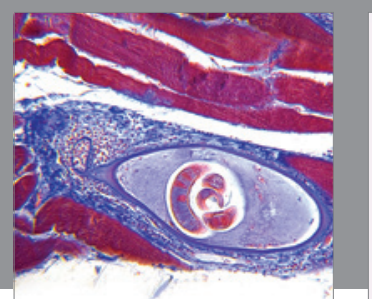

Gastroenterology Research and Practice

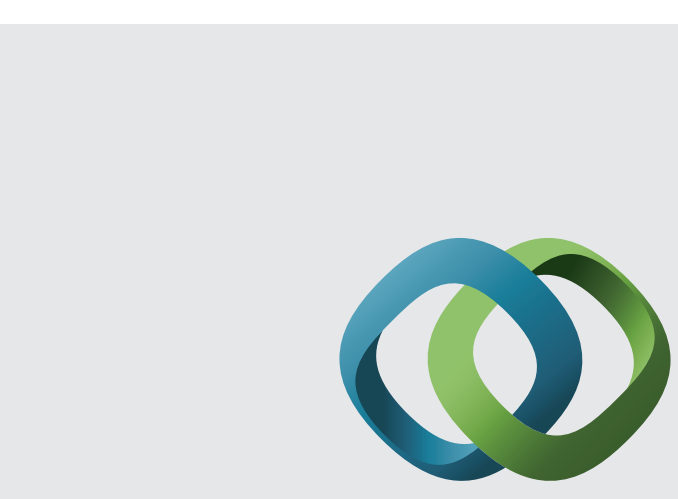

\section{Hindawi}

Submit your manuscripts at

http://www.hindawi.com
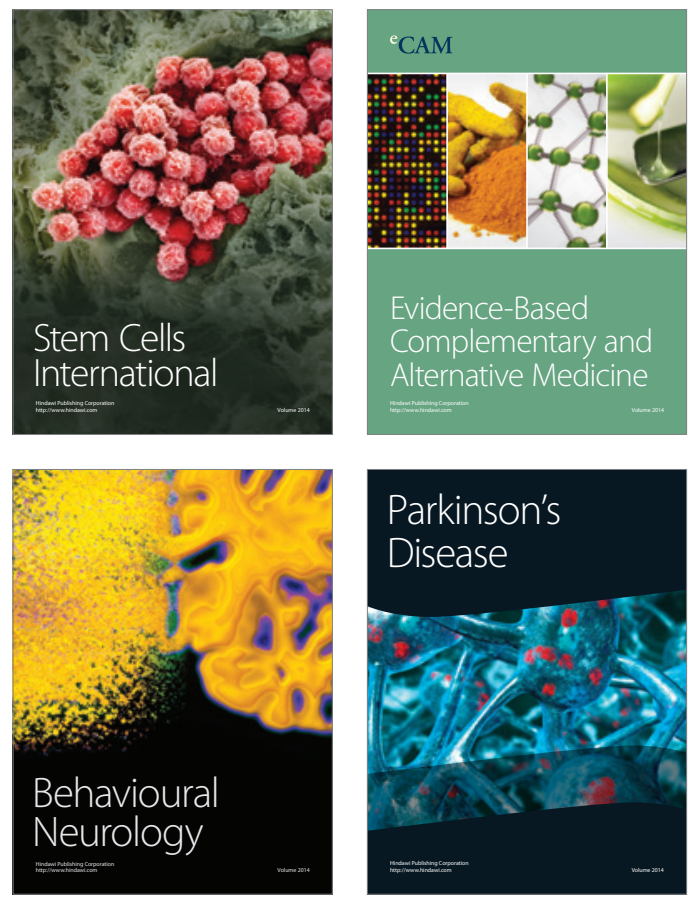
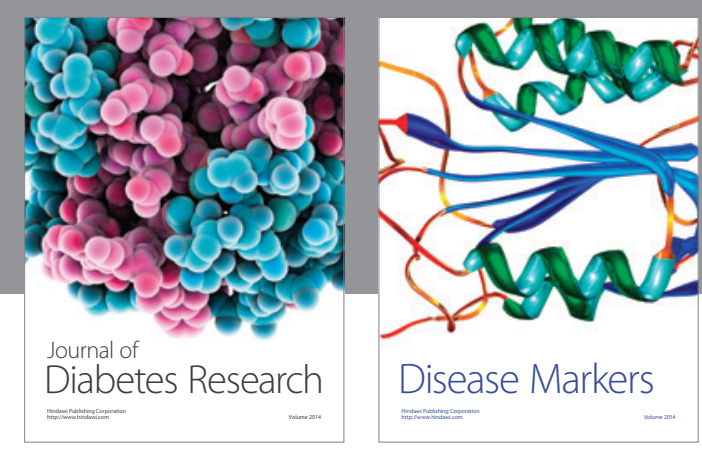

Disease Markers
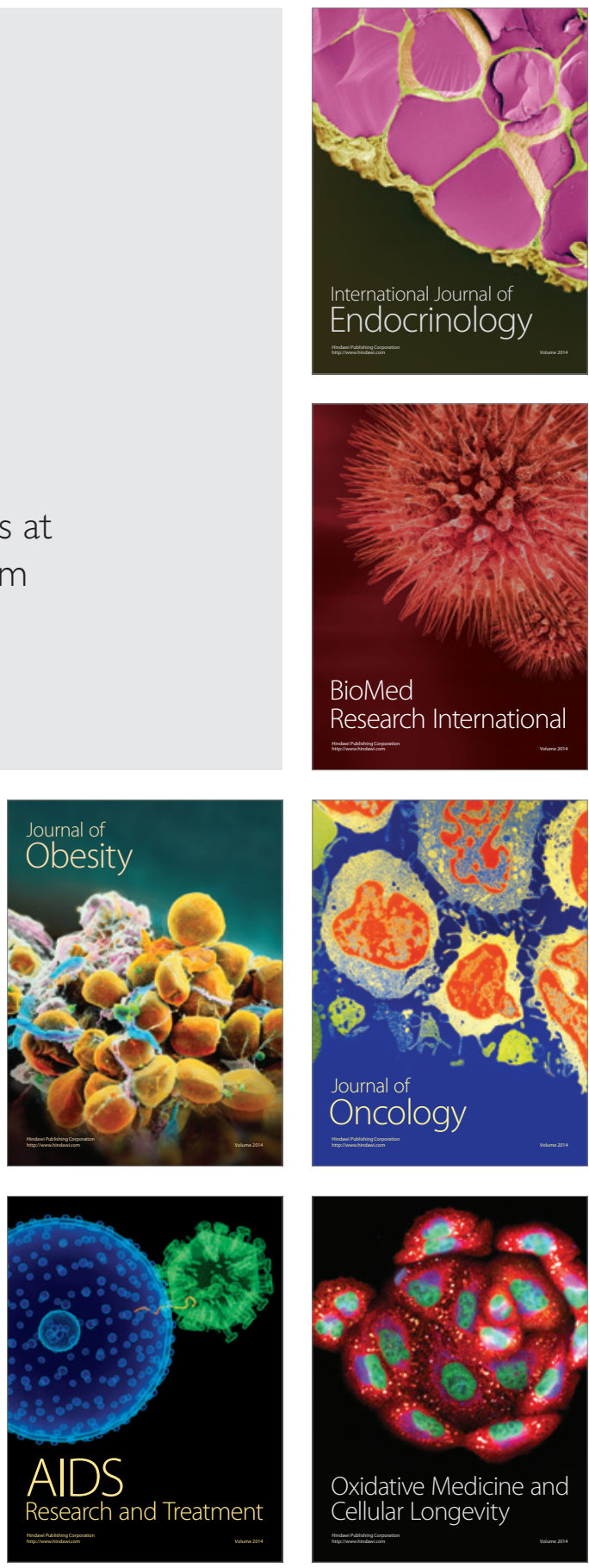